ments. As such, RAU awards double qualifications and has 3I departments within five schools. The university delivers several joint graduate-level programs with partner universities in Russia and Europe. It also has several research clusters.

- The French University in Armenia (UFAR), established on the basis of an interstate agreement between the two governments and collaborating with Jean Moulin Lyon 3 University via a franchising agreement. UFAR is a private nonprofit foundation awarding double qualifications.

- The European Regional Educational Academy of Armenia (EREA), another interstate, nonprofit, public foundation. The Academy was created by decision of the Armenian government and on the basis of franchising agreements signed with a number of educational institutions from various European countries. The institution awards Armenian qualifications.

According to the national ranking system, two of these universities, AUA and RAU, are competitive in the Armenian education system and ranked as second and third respectively.

Meanwhile, there are seven branches of Russian, Ukrainian, and Belarusian universities active in Armenia. These campuses award the qualifications of their parent institutions. Given that there is no publicly available information on these institutions, the number of graduates from these branches is not clear, nor is it possible to say much about the quality of the education they offer.

The Yerevan Branch of Lomonosov Moscow State University (MSU) is quite new in the Armenian higher education landscape. It was launched in 2015 and has not graduated any students as yet. MSU offers undergraduate programs in seven disciplinary areas; most of them overlap with areas offered by RAU, which raises the question of whether these two universities will compete for the same student population. On the other hand, the arrival of MSU on the market might add value to the growing internationalization of the sector by attracting more students from the Commonwealth of Independent States (CIS) countries.

\section{What Does the Future Hold?}

Although the number of private institutions in Armenia is large, the majority of students (about 87 percent) still choose to enroll in public and interstate institutions, even though they are costly. Approximately I5 percent of learners choose cross-border institutions, and this percentage is growing steadily. These figures, together with the evaluation results of national rankings-where private universities occupy lower positions-tell us that the quality of pri- vate institutions in Armenia is low, and that they are not yet strong competitors.

In contrast, transnational education institutions are becoming more attractive because they offer students the opportunity to study in a language other than Armenian. Given that legislation hinders national HEIs from delivering their programs in foreign languages, unequal conditions for transnational and national institutions exist and contribute to growing complaints from national universities.

In light of these various factors, the popularity of crossborder education in Armenia will likely increase, driving national institutions to pursue stronger internationalization policies in order to compete.

DOI: http://dx.doi.org/I0.60I7/ihe.20I7.9I.I004I

\section{Higher Education in Mauritius: Challenges and Perspectives of International- ization}

\section{Shaheen Motala Timol and Kevin Kinser}

Shaheen Motala Timol is quality assurance and accreditation officer at the Tertiary Education Commission, a 2016-2017 Hubert H. Humphrey Fellow at Pennsylvania State University, and a visiting scholar at the Center for International Higher Education, Boston College, US. E-mail:sam776@psu.edu. Kevin Kinser is professor and head of the Department of Education Policy Studies at Pennsylvania State University, US, and codirector of the Cross-Border Education Research Team (C-BERT).E-mail: kpkg@psu.edu.

T $\mathrm{n}$ an effort to align itself with global trends in higher 1 education, Mauritius has since the late I990s identified internationalization as a key strategy to achieve knowledge hub status and become a regional center of excellence. In 2000 , the government brought forward this vision in its New Economic Agenda. The island has specific advantages supporting its aspiration to achieve this goal, from its strategic location in the Indian Ocean to its historical relationship with Europe and its bilingual educational system. Since its independence in 1968, Mauritius has already proven that it is a global player in several sectors by being innovative in its approach to economic growth and diversifying from traditional sectors to service sectors. This article discusses Mauritius' approach to establish higher education as a major pillar of its economy through internationalization, and the challenges it has faced. 


\section{The Development of a Knowledge-Based Economy}

The 2000 Agenda to develop Mauritius into a knowledge hub served to catalyze the existing internationalization activities in the higher education sector. In fact, since the late I990s, public and private institutions in Mauritius had already been engaged in internationalization through crossborder education, mostly in collaboration with universities from developed countries. Private institutions offered programs through franchise partnerships and some also enrolled students on overseas distance education programs. Public universities were collaborating with foreign universities to offer joint degrees in fields where there was a lack of local expertise. Appointment of foreign external examiners by public institutions also brought an international dimension to programs and curricula, ensuring they aligned with international standards.

The Tertiary Education Commission (TEC), a regulatory body for higher education, was established in I988 to oversee the sector. In 2007 , TEC was invested with additional powers when the existing regulatory framework was consolidated. In 20I0, new momentum was given to the vision to transform Mauritius into a knowledge-based economy with the establishment of a separate ministry for tertiary education. TEC defined and implemented measures to reach the objectives of the government. As opposed to the gradual, incremental approach adopted previously, a bolder strategy was chosen. Locally, the goal was to democratize higher education in order to have one graduate per family. The internationalization goals were to attract I0०,000 international students and at least one world-class institution by 2020 . The ministry created a "one-stop bureau," Study Mauritius, to cater to the needs of foreign students. Private institutions already experienced in cross-border education were encouraged to expand access to their programs and to partner with renowned universities. Administrative procedures for international student visas were expedited. The Board of Investment organized student fairs and investment promotion strategies in the region, in collaboration with TEC and higher education institutions.

\section{The Hurdles of Internationalization}

Implementing and piloting the new measures was not without risks or unintended consequences. Opening access to higher education by lowering the entry threshold or offering alternative routes undeniably impacted the quality of recruitment, and consequently, the quality of education and employability. The government introduced different training schemes for unemployed youth and graduates, the latest one being the Graduate Training for Employment scheme of 2015, which aims to equip unemployed graduates with relevant skills to enhance their employability. Enrollments in public universities, which stood at around
9,000 in 2000 , grew to 22,800 in 20I4. Public universities were unprepared to service more students without additional resources. Although they were engaged in internationalization activities, they had no formal internationalization policies. Their market remained limited to local students, except in cases where they affiliated with private medical schools. Strengthening the University of Mauritius, the oldest and premier university in the country, would have been the wisest decision in the effort to become a knowledge hub. A foreign vice-chancellor was appointed in 2010 to bring international perspective to the university leadership, but he resigned in 20I2. Meanwhile, two new universities were created in 20I2. One was dedicated to distance education. The other was the result of a merger between two polytechnics.

In the period from 2000 to 2014 , enrollments in private institutions rose from 5,250 to 18,000 , but these were not yet attractive to international students. Out of 50 private institutions, only few had campus facilities, a factor that international students consider when choosing an institution. Courses on offer at private institutions were also costlier, which represented a financial barrier for full-time students. Some private institutions took advantage of the new government policies to attract international students and went on

\section{The government of Mauritius is pres- ently engaged in a process of consoli- dation of its legislation impacting the higher education sector.}

student recruiting sprees in countries such as Bangladesh, highlighting programs that had no formal entry requirement. Some international students came to Mauritius to work rather than study, and in the process paid large fees to overseas recruiting agencies. Regulating these ad hoc issues, as well as ensuring that private institutions were more accountable for their international marketing strategies, was beyond the purview of TEC.

Branch campuses are important elements in the internationalization of higher education in this context. Middlesex University and Wolverhampton University in the United Kingdom and EIILM University in India established branches in Mauritius prior to 20I4. Following public communiqués in 2013 by the University Grants Commission in India, which did not authorize Indian universities to establish offshore campuses abroad, the operation of EIILM University (Mauritius Branch Campus) came to an end. The Wolverhampton University branch campus closed its doors 
in 20I5, probably due to low student enrollments. Another UK institution, Coventry University, was unsuccessful in sustaining its collaborative venture in Mauritius.

Although the number of international students tripled from 2010 to 2015 from around 500 to I,500 students (with enrollments from Africa steadily growing), the critical mass of international students needed for Mauritius to establish itself as a knowledge hub was far from being reached. In addition, the regulations of the TEC, unchanged since 2007 , were not revised to provide sufficient incentives for worldclass universities to risk setting up branch campuses in Mauritius.

By the end of 20I4, TEC was juggling many new challenges. Increasing the number of international students had created a demand for additional services beyond education. Several ministries had to revise their policies on health, labor, housing, and immigration to support internationalization, and had to make concerted efforts to resolve issues related to the arrival of new international students.

\section{Where Do We Stand Now?}

With the election of a new government in December 20I4, the ministry of tertiary education was closed down and tertiary education was again integrated under the umbrella of the ministry of education. Since then, TEC has adopted a cautious stance in its quality assurance activities. The government of Mauritius is presently engaged in a process of consolidation of its legislation impacting the higher education sector.

Some lessons on implementing internationalization are evident from the case of Mauritius. First, internationalization has to be planned sustainably and include all stakeholders. Second, goals can be achieved with robust regulatory measures to encourage innovative ventures and to prevent abuse. Third, public universities need strong leadership that drives internationalization. Fourth, a tailored strategy has to be devised for private institutions, which have different agendas. Fifth, high-quality foreign universities need both a supportive infrastructure and appropriate incentives to be attracted to a new country. And sixth, crossborder higher education needs to be scaffolded by mutually beneficial interregulatory agreements.

These last years have been turbulent times but have offered a rich learning experience for the country to better plan and pursue the internationalization of its higher education ecosystem. Mauritius needs to leverage its unique contextual advantages and design a culturally informed regulatory framework, to align with its dynamic higher education sector.

DOI: http://dx.doi.org/10.60I7/ihe.20I7.91.10040

\section{Higher Education Interna- tionalization in Ukraine: Concerns and Hope}

IRINA SIKORSKAYA

Irina Sikorskaya is senior researcher at the Institute of Higher Education of the National Academy of Educational Sciences, Kiev, Ukraine. E-mail: irinasikorskaya0207@gmail.com.

$\Delta$ s part of a wider effort to upgrade educational services Ato international standards of excellence, Ukrainian higher education institutions (HEIs) have recently undertaken an increasing number of international activities. After decades of isolation, Ukrainian HEIs have gradually embraced internationalization, particularly academic mobility initiatives and double degree programs, and by encouraging more faculty and students from other countries to set up ties with HEIs in Ukraine. From 2005 onward, the Bologna Declaration guidelines have gained increasing strategic importance, and internationalization of higher education has become a topical issue in Ukraine. It is important to note that while historically, national political motives have been the key driving force behind the implementation of reforms at the institutional level, the role of the central government in the reform process today is limited to issuing educational guidelines and supervising their implementation.

\section{Internationalization from the Institutional Perspec- TIVE}

Due to common social, academic, and historical context, international activities at Ukrainian HEIs have a certain degree of similarity. Currently, they rest mostly on three major pillars: the recruitment of foreign students; the organization of student and staff mobility; and participation in international projects.

To a large extent, internationalization occurs in a fragmented rather than systemic way and is not shaped by a given institution's mission, traditions, or current context. This could be attributed to a lack of leadership-level management skills across institutions in the higher education sector. However, the acknowledgement of the importance of internationalization by the senior leadership, at least in words, is an indication that the system is moving in the right direction.

In the majority of HEIs, the principal focus is on recruiting international students. Ukrainian HEIs seek to attract international students in order to earn income and gain recognition. Still, the main barriers to the admission of foreigners are language proficiency, visa requirements, bureaucracy, finding suitable accommodation, credit recog- 